\title{
Painless aortic dissection, presenting as dyspnoea
}

\author{
Rohith Reddy Poondru, ${ }^{1}$ Naresh Monigari, ${ }^{2}$ Ranjan K Shetty, ${ }^{1}$ Ganapathiraman Vivek ${ }^{1}$
}

${ }^{1}$ Department of Cardiology, Kasturba Medical College, Manipal, Karnataka, India ${ }^{2}$ Department of Medicine, Kasturba Medical College, Manipal, Karnataka, India

\section{Correspondence to} Dr Naresh Monigari, medico.ktya@gmail.com
CrossMark

To cite: Poondru RR, Monigari N, Shetty RK, et al. BMJ Case Rep Published online: [please include Day Month Year] doi:10.1136/ bcr-2014-203623

\section{DESCRIPTION}

We report an 84-year-old woman, a known case of chronic obstructive pulmonary disease (COPD), who presented with a 4-day history of fever and worsening dyspnoea. No history of chest pain was elicitable. Systemic examination was suggestive of left-sided pleural effusion. Biochemical investigations (NT-pro brain natriuretic peptide level was

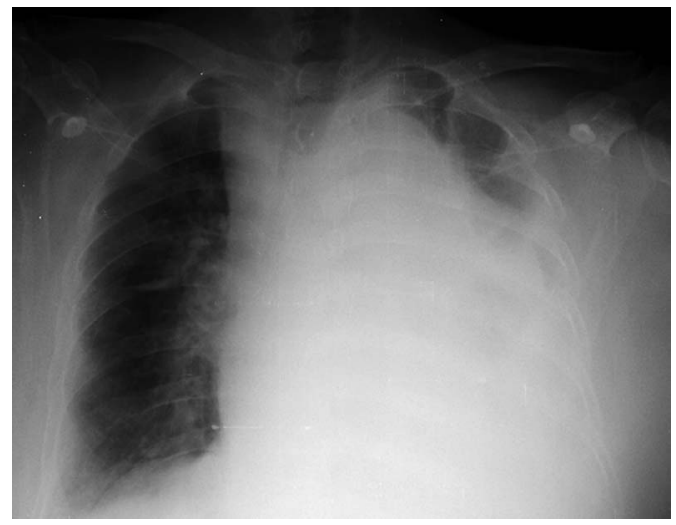

Figure 1 Chest radiograph showing left-sided gross pleural effusion.
$10000 \mathrm{pg} / \mathrm{mL}$ with cut-off being $300 \mathrm{pg} / \mathrm{mL}$ ) suggested a probable diagnosis of acute congestive heart failure (CHF). Her chest radiograph revealed left-sided gross pleural effusion (figure 1). In view of the atypical presentation and failure to respond to diuretic therapy, alternative diagnoses were considered. Aortic dissection (AD) was not considered initially as she never had chest pain or uncontrolled hypertension. ${ }^{1}$ Cardiac echocardiogram visualised an intimal flap in the descending aorta raising the possibility of AD. A CT scan of chest revealed Stanford type B AD (figures 2 and 3). The patient's condition deteriorated rapidly and she expired prior to definitive repair. AD is a relatively rare but dreadful illness, often presenting with tearing chest pain. Early diagnosis and treatment are essential for survival. Painless AD may constitute $5-15 \%$ of $\mathrm{AD}^{1}$. Acute sudden onset of severe pain is the typical manifestation of $\mathrm{AD}$, but a wide variety of symptoms can be present. ${ }^{2}$ Rare presentations of $\mathrm{AD}$ are $\mathrm{CHF}^{1}{ }^{1}$ stroke $^{3}$ or paraplegia. ${ }^{4}$ Painless $\mathrm{AD}$ is rare and often under-recognised; $\mathrm{AD}$ has to be ruled out if diagnosis is in suspicion. Study performed by Park et $a l^{5}$ showed association of higher mortality in patients with painless AD and more so when $\mathrm{AD}$ is of type $\mathrm{B}$.
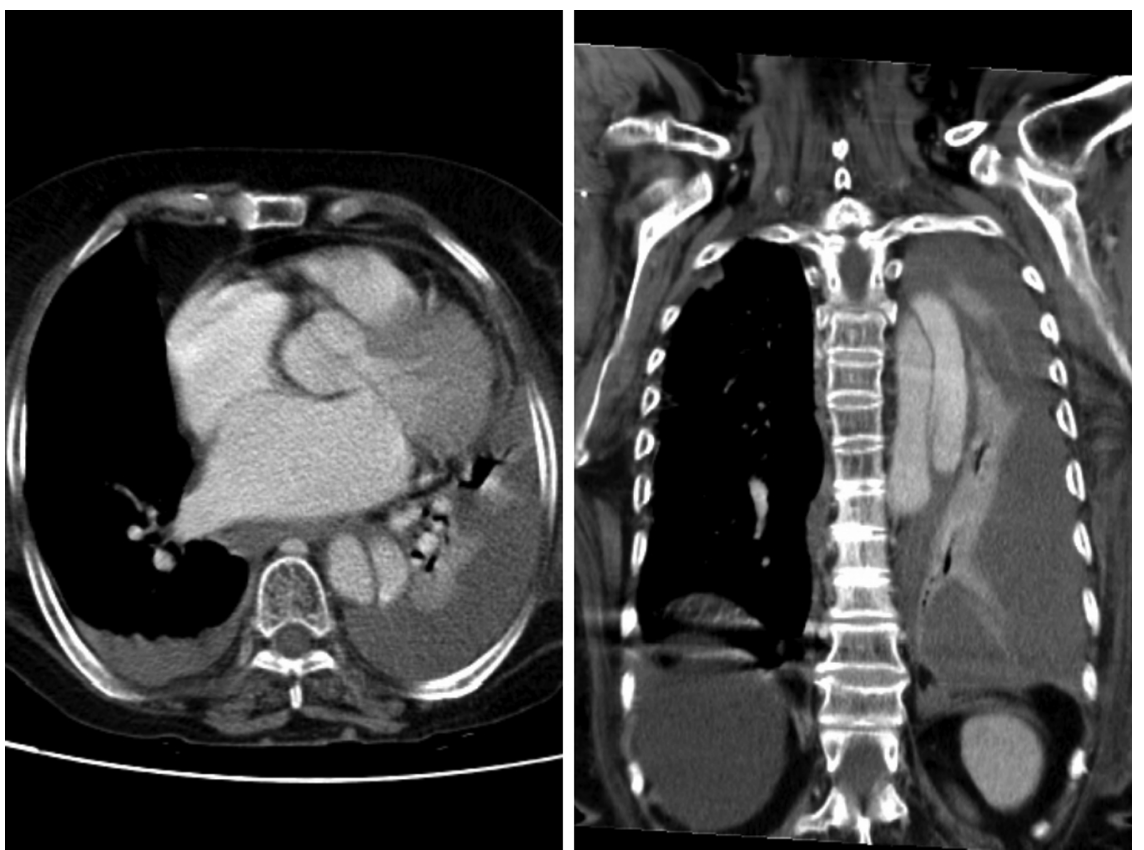

Figure 2 CT of the chest showing true and false lumen involving descending thoracic aorta distal to the branch of left subclavian artery for a length of $10.3 \mathrm{~cm}$ with the true lumen displaced medially suggestive of Stanford type B aortic dissection. 


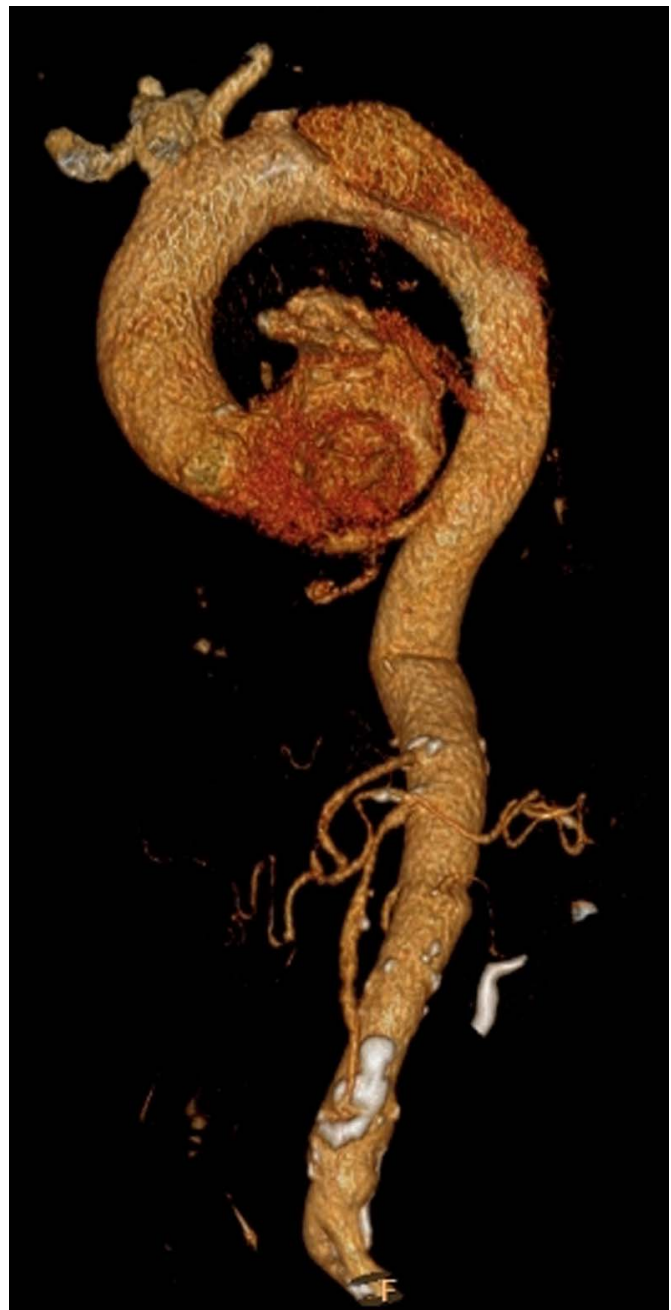

Figure 3 Three-dimensional reconstruction of CT scan image showing the extent of aortic dissection.

\section{Learning points}

- Aortic dissection (AD) is a rare and dreadful condition; mortality can be improved with early diagnosis and treatment.

- In $A D$, early diagnosis is critical because early intervention can decrease the mortality rate, which is estimated to increase by $1-2 \%$ per hour in the first $48 \mathrm{~h}$ of ascending AD. ${ }^{6}$

- Although typically manifested by tearing chest pain, in presence of congestive heart failure, stroke, shock or loss of distal pulse, AD should be suspected.

- Painless conditions have been rarely reported and keen observation is required to diagnose such cases as immediate treatment can improve survival.

Contributors NM was involved in preparing the manuscript. RRP, RKS and GV reviewed the manuscript and approved the final version for submission.

Competing interests None.

Patient consent Obtained.

Provenance and peer review Not commissioned; externally peer reviewed.

\section{REFERENCES}

1 Liu JF, Ge QM, Chen M, et al. Painless type B aortic dissection presenting as acute congestive heart failure. Am J Emerg Med 2010;28:646.e5-7.

2 Nienaber CA, Fattori R, Lund G, et al. Nonsurgical reconstruction of thoracic aortic dissection by stent-graft placement. N Engl J Med 1999;340:1539-45.

3 Morita S, Shibata M, Nakagawa Y, et al. Painless acute aortic dissection with a left hemiparesis: a case report. J Stroke Cerebrovasc Dis 2005;14:36-8.

4 Colak N, Nazli Y, Alpay MF, et al. Painless aortic dissection presenting as paraplegia. Tex Heart Inst J 2012:39:273-6.

5 Park SW, Hutchison S, Mehta RH, et al. Association of painless acute aortic dissection with increased mortality. Mayo Clin Proc 2004;79:1252-7.

6 Tsai TT, Nienaber CA, Eagle KA. Acute aortic syndromes. Circulation 2005:112:3802-13.

Copyright 2014 BMJ Publishing Group. All rights reserved. For permission to reuse any of this content visit http://group.bmj.com/group/rights-licensing/permissions.

BMJ Case Report Fellows may re-use this article for personal use and teaching without any further permission.

Become a Fellow of BMJ Case Reports today and you can:

- Submit as many cases as you like

- Enjoy fast sympathetic peer review and rapid publication of accepted articles

- Access all the published articles

- Re-use any of the published material for personal use and teaching without further permission

For information on Institutional Fellowships contact consortiasales@bmjgroup.com

Visit casereports.bmj.com for more articles like this and to become a Fellow 